\title{
Release site manipulation to favour European ground squirrel Spermophilus citellus translocations: translocation and habitat manipulation
}

Author(s): Csongor István Gedeon, Gábor Boross, András Németh, and Vilmos

Altbäcker

Source: Wildlife Biology, 18(1):97-104. 2012.

Published By: Nordic Board for Wildlife Research

DOI: http://dx.doi.org/10.2981/10-124

URL: http://www.bioone.org/doi/full/10.2981/10-124

BioOne (www.bioone.org) is a nonprofit, online aggregation of core research in the biological, ecological, and environmental sciences. BioOne provides a sustainable online platform for over 170 journals and books published by nonprofit societies, associations, museums, institutions, and presses.

Your use of this PDF, the BioOne Web site, and all posted and associated content indicates your acceptance of BioOne's Terms of Use, available at www.bioone.org/page/terms_of_use.

Usage of BioOne content is strictly limited to personal, educational, and non-commercial use. Commercial inquiries or rights and permissions requests should be directed to the individual publisher as copyright holder. 


\title{
Release site manipulation to favour European ground squirrel Spermophilus citellus translocations: translocation and habitat manipulation
}

\author{
Csongor István Gedeon, Gábor Boross, András Németh \& Vilmos Altbäcker
}

Translocating European ground squirrels Spermophilus citellus has become a popular conservation tool. However, few release techniques have been carefully evaluated. To contribute to an evidence-based ground squirrel translocation guide for wildlife managers, we evaluated conditions of habitat manipulation (grass height and artificial burrow entrance angle) which we expected to affect settlement of translocated ground squirrels during the critical period after release. In a field experiment, we translocated 173 individuals in southeastern Hungary in 2007. We released the animals into angled or vertical artificial burrows and manipulated grass height. We found that animals preferred angled $\left(\sim 30^{\circ}\right)$ artificial burrows, which facilitate digging, and medium-height grass $(18 \mathrm{~cm} \pm 1.5)$. Moreover, although ground squirrels generally are associated with short grass habitats, overhead protection by grasses is valuable after a translocation. This result implies that in order to accomplish a translocation, it is not sufficient to only know the habitat preference of a species in undisturbed situations, but also how and to what extent habitat characteristics should be manipulated to increase the chances of success.

Key words: burrow entrance angle, critical period, European ground squirrel, grass height, Spermophilus citellus, translocation

Csongor István Gedeon, HAS, Research Institute for Soil Science and Agricultural Chemistry, Hermann O. u. 15,1022 Budapest, Hungary and Eötvös Loránd University, Department of Ethology, Pázmány P. s. 1/c, 1117 Budapest, Hungary e-mail: csongorg@gmail.com

Gábor Boross, András Németh \& Vilmos Altbäcker, Eötvös Loránd University, Department of Ethology, Pázmány P.s. 1/c, 1117 Budapest, Hungary - e-mail addresses: gaborboross@yahoo.com (Gábor Boross); nemethandras2@gmail.com (András Németh); altbac@gmail.com (Vilmos Altbäcker)

Corresponding author: Csongor István Gedeon

Received 19 November 2010, accepted 25 July 2011

Associate Editor: Scott Newey

Translocating animals within their natural distribution range is a popular tool in wildlife management and conservation (Bajomi et al. 2010), and it is often used to reestablish populations of endangered species (IUCN 1998, Fischer \& Lindenmayer 2000, Seddon et al. 2007). According to Teixeira et al. (2007), translocations bear three main challenges: 1) survival of the animals after release, 2) settlement of animals in the release area, and 3) successful reproduction. Although there is no general agreement on the criteria for the success of translocations (Seddon 1999), survival in the early post-release period is critical (Griffith et al. 1989, Miller et al. 1999, Gerber et al. 2003, Cheyne 2006, Moorhouse et al. 2009). On the basis of data collected in earlier translocations of European ground squirrels Spermophilus citellus (V. Altbäcker, unpubl. data), this early, post-release period is estimated to encompass two weeks post-release for European ground squirrels. During this critical period, mortality was the highest in previous translocations.

Habitat quality at the release site is one of the most important factors to be addressed in a reintroduction (IUCN 1998). For ground dwelling sciurids, the 
habitat encompasses both the above-ground and underground environments. For natural colonies of ground squirrels, grass height is one of the most important factors of the above-ground environment to favour survival of colonies (Kis et al. 1998). Animals abandon sites where the grass grows tall and settle where short grassland is established. Ground squirrels have long and elaborated burrow systems (Ružić 1978), which provide a stable and safe environment against predators and unpleasant environmental conditions (Hut \& Scharff 1998). Burrow entrances can be divided into two types: vertical burrows (pointing straight down at an angle of $90^{\circ}$ to a horizontal surface) and angled burrows (sloping in one direction at an angle of $30-35^{\circ}$ to a horizontal surface) (Ružić 1978, Hut \& Scharff 1998). The average number of entrances per burrow system and individual is four (Hut \& Scharff 1998, V. Altbäcker, unpubl. data).

As ground dwelling sciurids strongly depend on their burrow systems, the use of artificial burrows and acclimation cages is recognised as an essential tool in reintroductions (Anstee \& Armstrong 2001, Truett et al. 2001, Simms 2009). During reintroductions of ground squirrels, wildlife managers in Hungary usually apply vertical artificial burrows which are easier to drill. However, there is a lack of data that allow assessing whether angled or vertical artificial burrows better facilitate settlement in the critical period after release.

The European ground squirrel is an obligate hibernator whose reproduction is limited by a relatively short active season, and it is a species of special conservation concern. In the 2011 IUCN Red List of Threatened Species, it is listed as vulnerable with a decreasing population trend (IUCN 2011). However, as the ground squirrel has adapted well to live in grassy recreational parks (Hoffmann et al. 2008) and airports (Váczi et al. 2006), local high densities can create damage and safety concerns, since raptors that prey on ground squirrels may result in collision risks for airplanes, and burrow mounds can be potentially hazardous to small airplanes during landing and take-off. Thus, regulating its abundance by translocations is sometimes a remedy to solve the human-animal conflict (Massei et al. 2010).

In response to the decline in ground squirrel populations, reintroduction as a management tool has been used frequently, with several thousand animals translocated in Hungary and also Poland
(IUCN 2010). Nevertheless, only a few projects provide well-documented information that can be linked to the success or failure of these reintroductions. Consequently, nature conservation managers lack an evidence-based translocation guide for ground squirrel translocations.

In our study, we tested important determinants of pre-release habitat manipulation on the reintroduction success. We undertook a combined experiment to test and evaluate how 1) grass height on the release site and 2) entrance angle of artificially drilled burrows can influence successful settlement during the critical period after translocation of wild-caught ground squirrels. Both features can be implemented with careful design during planned translocations without additional costs.

\section{Material and methods}

On 14 and 15 July 2007, 173 reproductively active ground squirrels (about 1:1 sex ratio) were captured at Ferihegy International Airport $\left(47^{\circ} 25^{\prime} 8.88^{\prime \prime} \mathrm{N}\right.$, $\left.19^{\circ} 15^{\prime} 7.20^{\prime \prime} \mathrm{E}\right)$ and were released on 16 July 2007 to Szeri-puszta (46 $\left.31^{\prime} 19^{\prime \prime} \mathrm{N}, 20^{\circ} 04^{\prime} 44^{\prime \prime} \mathrm{E}\right)$, a protected grassland ( $\sim 150$ ha) in Kiskunság National Park, in the Duna-Tisza Köze region, Hungary. On the release site, ground squirrels went extinct $>10$ years before the translocation due to vegetation changes after termination of sheep grazing, and there were no ground squirrels or burrow remnants left. To provide short grass habitat for ground squirrels (Kis et al. 1998), grazing with sheep (Hungarian Merino Ovis aries aries merino and Racka Ovis aries aries racka) was restarted before our experiment. Additionally, during and after the translocation, we employed predator exclusion in the release site by guarding the animals continuously from hides for two weeks (Rouco et al. 2008). After the animals entered into daily rest in the burrows (including all night), guards applied spotlights for checking the area for predators.

Ground squirrel trapping was carried out by snaring (Gedeon et al. 2011). Until release into artificial burrows, captured animals were housed in separated wire cages $(10 \times 10 \times 40 \mathrm{~cm})$. All animals were released in the morning of the day after capture, and we used 0.5 litre retention bottles made of glass with low transparency to keep the animals in the burrows. Retention bottles were removed from the burrows the next day when we had confirmed that 


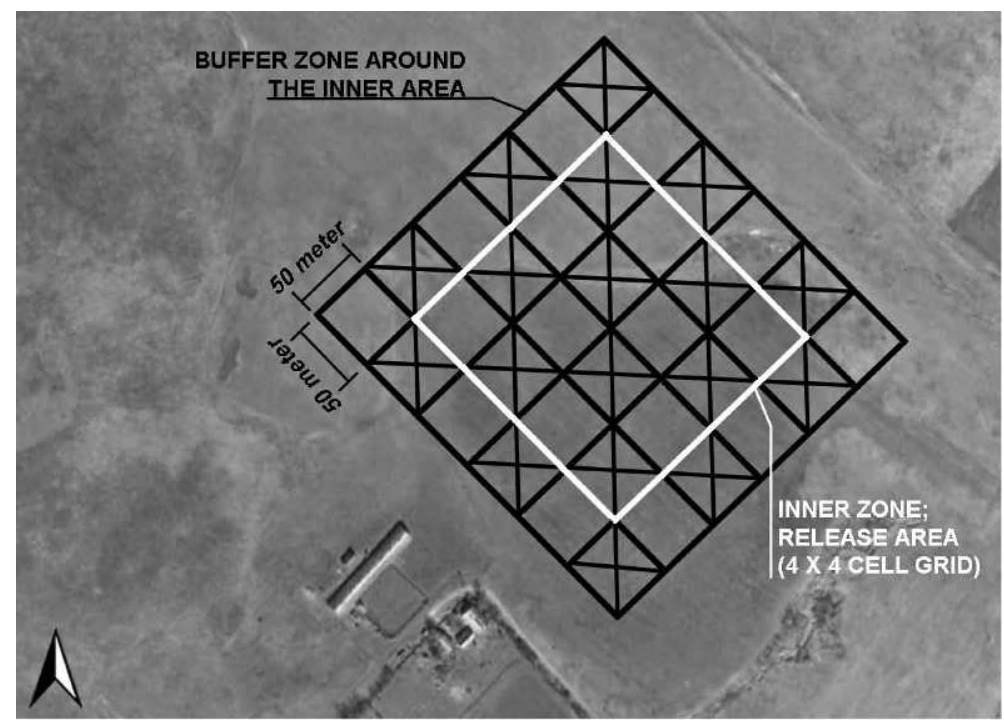

Figure 1. Map of the release site and the experimental design in Szeri-puszta (Google Earth $^{\mathrm{TM}}$ ). Crosses represent grid cells with medium-height grass.

animals were able to dig themselves out from the burrows.

The relocation site (a $6 \times 6$ cell grid; each grid cell being $50 \times 50 \mathrm{~m}$ ) included a $200 \times 200 \mathrm{~m}$ inner area $(4$ $\times 4$ cell grid), where the animals were released, and a $50 \times 50 \mathrm{~m}$ buffer zone around the inner area (Fig. 1). The release site was signed with signposts (49) in each grid cell corner, and within the inner area $(200 \times$ $200 \mathrm{~m}$ ), $50 \mathrm{~cm}$ long and $5 \mathrm{~cm}$ wide artificial burrows were drilled with an electric device (Makita BBA520, Japan). We drilled two kinds of artificial burrows: angled and vertical burrows, similar to the natural burrow types (see above). The order of artificial burrow types (angled or vertical) within a grid cell was tessellated and burrows were spaced $12.5 \mathrm{~m}$ in all directions. It resulted in a total of 256 artificial burrows in the inner area (16 grid cells), 128 angled and 128 vertical burrows, resulting in equal numbers of burrows in eight grid cells with medium-height (unmown) and in eight grid cells with short (mown) grass (see below). The animals were able to leave the artificial burrow only if they dug themselves out of the burrow as we plugged the animals in the burrow with retention bottles. In order to prevent introducing ground squirrels into an already occupied burrow because previously released animals had moved, all artificial burrows were plugged with bottles before the release. Plugs were removed immediately before the release to that particular burrow and placed back again. This method guaranteed one individual per one artificial burrow.

We released 11 ground squirrels in each grid cell, apart from one grid cell with short grass and two with medium-height grass where we released ten individuals, resulting in a total of 87 and 86 ground squirrels in short and medium-height grass, respectively, at the time of release. As regards the artificial burrows, we released 87 individuals into vertical and 86 individuals into angled burrows. Individuals were assigned to grid cells and burrows arbitrarily and without notice of sex and age. The grass height of the grid cells was alternately mown (short grass; mean = $6 \mathrm{~cm} \pm 0.5$; range: $0-14 \mathrm{~cm}$ ) or unmown (mediumheight grass; mean $=18 \mathrm{~cm} \pm 1.5$; range: $2-44 \mathrm{~cm}$ ) by a tractor before the release (see Fig. 1). Grass height was assessed during the experiment at each data record occasion by measuring the height of the longest blade of grass at nine randomly chosen locations within each grid cell (Váczi \& Altbäcker 2005).

We noted on a map of the release site if a burrow was occupied by an animal on each data recording day. We defined a burrow as occupied if fresh soil or fresh faecal pellets were at the burrow entrances. After the release, we counted the number of inhabited man-made (angled, vertical) burrows as well as burrows dug by the animals (new burrows) six times in each cell on the release site $(1,2,3,7,37$ and 72 days after release; 17, 18, 19, 23 July, 22 August and 26 September). After each data collection, we removed the indicators of occupancy (fresh soil or faecal pellets), so that at the next data collection, we did not record the burrow as occupied based on older signs. 


\section{Statistical analysis}

Statistical analyses were carried out using the STATISTICA data analysis software system (StatSoft Inc. 2009). We adopted a generalised linear modelling (GLM) with repeated measures (time) approach with three categorical variables (grass height, burrow type and burrow form) to predict the number of used burrows. The number of used burrows was counted six times from the time of release of ground squirrels until the end of the growing (active) season. Each categorical variable had two levels (burrow type: vertical or angled; burrow form: new or man-made; grass height: short or medium-height). As the response variable 'number of used burrows' was discrete, we assumed a Poisson distribution (Poisson regression). Because replication of samples was at the grid level (16 grid cells) and each category of burrow type was found only in combination with one of the categories of grass height, we applied a nested design. Because of the nested design, GLM procedures could only use the overparameterised model to compute ANOVAs.

Maintenance of short and medium-height grass during the experiment was tested by a general linear model repeated measures procedure. Between-subject factor was grass height and within-subject factor was time (days after release) with six levels, which corresponded to grass height measurements at six independent occasions.

Summary data are reported as means \pm SE, unless stated otherwise. The criterion for statistical significance was always $\mathrm{P}<0.05$. In figures, we illustrate the changes of grass height or number of inhabited burrows. Values on the x-axis show 'days after release'. As the time interval between consecutive data recording occasions was not even (data recording in days after the release: 1, 2, 3, 7, 37 and 72 ), it would have been difficult to illustrate the real differences between data recording days. Consequently, we transformed days after release (x-values) by applying a $\log 10$ transformation and illustrated these log-transformed values on the x-axis. As a result of this transformation, the difference between $\mathrm{x}$-values does not show the real time difference between days, but it provides better visual illustration of data than an unusually long $\mathrm{x}$-axis with real days from 1 to 72 .

Spatial independence of grid cells including used burrows was tested by spatial autocorrelation. A significantly positive coefficient would show spatial aggregation and a significantly negative coefficient would show segregation between data. Since these coefficients compare values for pairs of the average number of used burrows per grid cell, the set of grid cells was divided into distance classes (as lags according to the analysis) of $0,50,100,113,141$, $150,159,180$ and 211 metres. It means that the distance between the centres of two adjacent grid cells was minimum $50 \mathrm{~m}$ and the maximum distance between grid cells was about $211 \mathrm{~m}$. The distance between two grid cells was the linear distance in metres between the centres of the grid cell pairs. According to general recommendations, autocorrelation was tested at lags one to $\operatorname{lag} \mathrm{n} / 4$, where $\mathrm{n}$ is the total number of distance classes in the analysis.

\section{Results}

Significant grass height difference was maintained between short $(6 \mathrm{~cm} \pm 0.5)$ and medium-height (18 $\mathrm{cm} \pm 1.5)$ grass grid cells during the whole experiment (grass height: $\mathrm{F}=81.64, \mathrm{df}=1,14, \mathrm{P}<0.001$, days after release: $\mathrm{F}=11.71, \mathrm{df}=1,70, \mathrm{P}<0.001$, interactions: $\mathrm{F}=406.24, \mathrm{df}=1,14, \mathrm{P}<0.001$; Fig. 2). However, plant height on 'medium-height grass' grid cells decreased significantly between 37 and 72 days after release because of extreme drought during the experiment.

The results showed that the number of inhabited burrows changed significantly from the first day after the release until the 72nd day, at which time, all animals disappeared from the surface for hibernation (days after release effect: $\chi^{2}=22.08, \mathrm{df}=5, \mathrm{P}<$ 0.001; Fig. 3).

The number of inhabited artificial burrows decreased while the number of inhabited new burrows

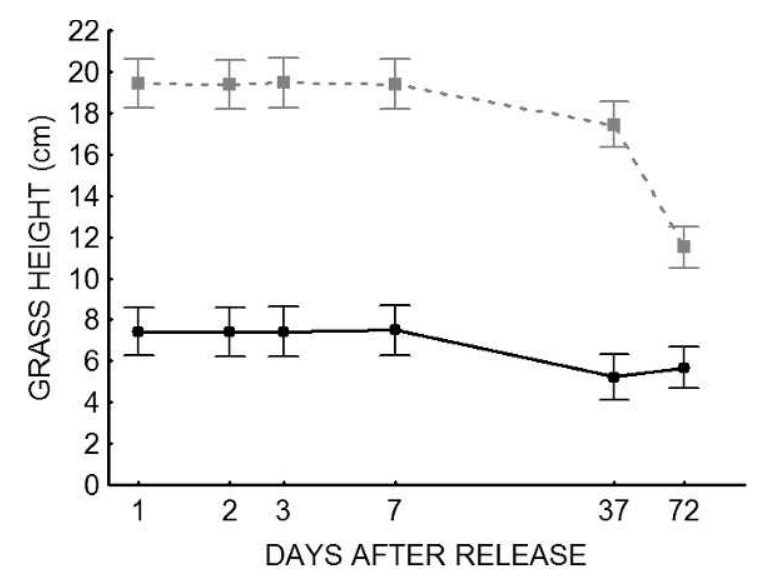

Figure 2. Change of the 'grass height' in the grid cells of the release site for 'medium-height' (grey) and 'short' grass (black). 


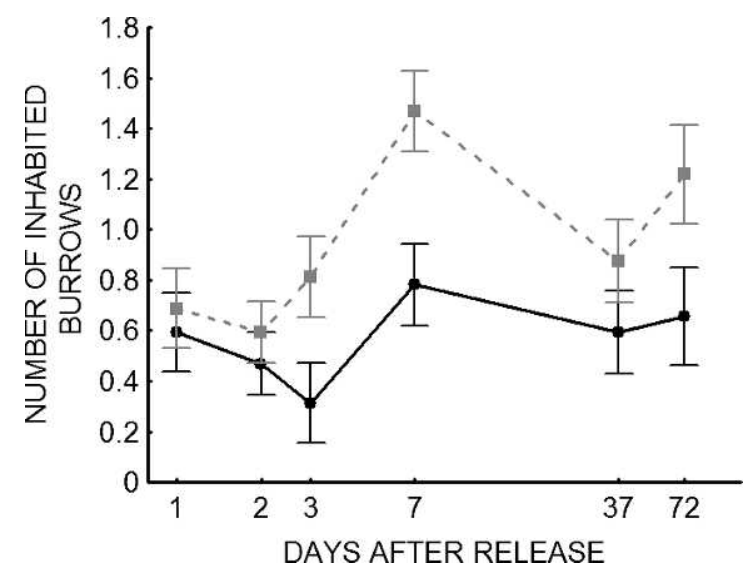

Figure 3. Number of inhabited burrows per grid cell (mean $\pm \mathrm{SE}$ ) in relation to 'days after release' (corresponding to 17, 18, 19, 23 July, 22 August and 26 September, 2007) and 'grass height'. 'Medium-height grass' is shown by a dashed grey line and 'short grass' by a solid black line.

increased during the experiment (Fig. 4A; burrow form (new or artificial) effect: $\chi^{2}=49.44, \mathrm{df}=1, \mathrm{P}<$ 0.0001 , burrow form (new) effect: parameter estimate of 'New' $=-0.86$, Wald statistic $=45.14, \mathrm{P}<$ $0.0001)$.

For artificial burrows, the overall difference between occupancy of angled and vertical artificial burrows was not statistically significant (burrow type effect (nested in grass height in the analysis): $\chi^{2}=3.21, \mathrm{df}=1, \mathrm{P}=0.22$ ). It also appeared that burrow type effect was not statistically significant for the number of inhabited burrows (burrow type (nested in grass height) effect: $\mathrm{P}>0.15$ ). Nevertheless, we found that burrow occupancy changed from the first day until the 72nd day. For only angled burrows, occupancy first increased and then decreased, with a peak on the seventh day after release (see Fig. 4B). Contrarily, the number of inhabited vertical burrows increased steadily from the first day after release.

The $\chi^{2}$-value for the difference between the number of inhabited artificial burrows in short vs medium-height grass was highly significant $\left(\chi^{2}=\right.$ 18.06, $\mathrm{df}=1, \mathrm{P}<0.0001$; see Fig. 3). Thus, burrow occupancy was related to grass height.

Autocorrelation coefficients and figures did not indicate spatial dependencies. In other words, there were no lags with values outside the confidence limit and autocorrelation coefficients were weak and not significant $(\mathrm{P}>0.7$ for each lags). Consequently, we can conclude that grid cells were spatially independent and there was no sign of serious habitat heterogeneity on the release site.
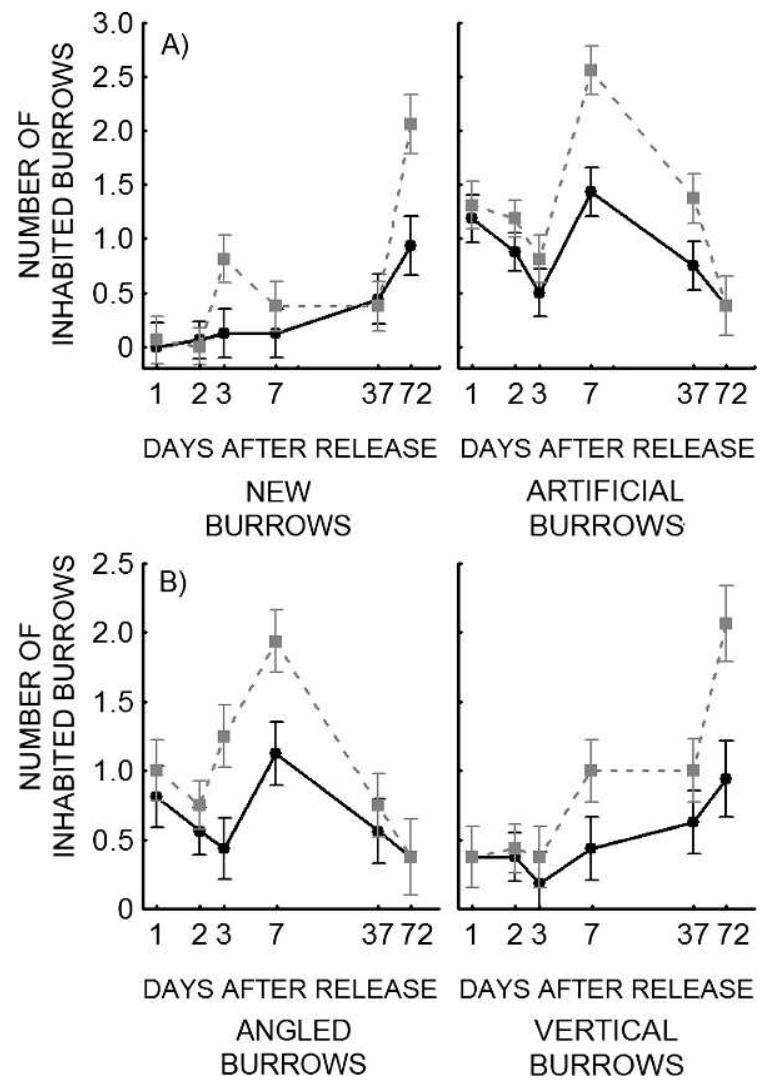

Figure 4. Number of inhabited burrows per grid cell (mean $\pm \mathrm{SE}$ ) in relation to 'days after release' (corresponding to 17, 18, 19, 23 July, 22 August and 26 September, 2007) and 'burrow form (new or artificial)' and 'grass height' (A), and 'burrow type (angled or vertical)' and 'grass height' (B). 'Medium-height grass' is shown by a dashed grey line and 'short grass' by a solid black line.

We did not find dead animals in or near the burrows after the translocation (the bottom of artificial burrows appeared empty when investigated using a torch). This shows that plugging with bottles permitted the animals to dig out of the burrows and did not result in extreme cooling or loss of the animals within the burrows.

\section{Discussion}

Our results suggest that angled artificial burrows in comparison with vertical artificial burrows and medium-height grass in comparison with short grass favour translocation success of European ground squirrels in the critical period after release. The artificial burrows, as expected from earlier findings (Truett et al. 2001, Simms 2009), provided shelter and refugia for the animals in the critical period 
before they excavated their own burrow system. This result is in accordance with the finding of Ružić (1978), whose study implied that angled burrows are dug from the outside in contrast to vertical ones, in which scratch digging is expected to be very hard, because the excavated soil would fall back on the digger.

Environmental conditions (i.e. precipitation and temperature) were stable during the translocation (from release until end of September). It means that random environmental variation did not strongly affect our habitat treatments and their effect on burrow occupancy. Consequently, the end of the critical period can be estimated more closely in the light of the results regarding burrow occupancy (artificial and new burrows). The increasing trend of artificial burrow usage (both vertical and angled burrows) changed to decreasing between the seventh (23 July; highest number of inhabited artificial burrows) and the 37th day (22 August) after the release. In parallel, the number of new burrows dug by the animals began to increase more intensively around the seventh day after release. The opposite trend of the usage of different burrows (artificial vs new and angled vs vertical) in response to days after release may have weakened the specific, individual effect of these parameters in the generalised linear model. Moreover, it seems that grass height effect exceeded burrow type effect, consequently, and because of the nested design, it was not possible to separate these effects. Nevertheless, the results clearly show that angled artificial burrows were preferred over vertical ones in the initial critical period (see Fig. 4B). All in all, we might conclude that the critical period ended between days seven and 37 after the release. This means that within this period, the translocated animals got over the stress caused by capture and release in a new habitat (Teixeira et al. 2007). This finding is in accordance with the result of Calvete \& Estrada (2004) who determined the critical period for translocated rabbits Oryctolagus cuniculus at about 7-10 days after release. Nevertheless, as we lack additional sampling events during these 30 days, we are not able to specify more precisely the length of the critical postrelease period.

It should be noted that numbers of inhabited burrows were always greater than the numbers of observed animals on the release site. This discrepancy requires some explanation. First, microrelief at the release site was unfavourable for visual observations in the area. Second, the size of the animals' home range (Turrini et al. 2008) and the grid cell area per capita (between 208 and $227 \mathrm{~m}^{2}$ ) is comparable in magnitude. Therefore, the animals may have left the home grid cell for feeding and exploration, resulting in positions different from the home grid during the observation periods. Additionally, since surplus (256 burrows were drilled, but only 173 ground squirrels were captured and released), artificial burrows were plugged throughout the study before the animals were released, all burrow occupancies represented one ground squirrel (double counting was avoided by this method; animals were not able to use these extra burrows). Parallel usage of new and artificial burrows cannot be excluded, but one individual usually uses one burrow system (Hut \& Scharff 1998, Millesi et al. 1998), and scattered positions of new and artificial burrows implied that parallel use was unlikely. Consequently, we were better able to detect the presence and location of the animals in the grid by counting occupied burrows than by visual scanning or census of animals. Burrow occupancy records seemed a more reliable and conservative technique than visual census.

Our results also suggest that vegetation height at the release site may affect settlement of released ground squirrels. In relocating water voles Arvicola terrestris, Moorhouse et al. (2009) concluded that the proper habitat characteristics were vital for longterm persistence. Kis et al. (1998) suggested that ground squirrels prefer short vegetation to tall grass. There are several hypotheses for the preference of short grass in the diurnal ground squirrel under natural conditions: 1) short grass enables predator detection, 2) it helps in communication between conspecifics, and 3) moving and navigation may require less energy in shorter than in taller grass. Newly translocated individuals, however, may have divergent preferences. Our results showed that released ground squirrels at least initially preferred to settle in medium-height over short grass areas, probably because grass tussocks provided overhead protection (see also Ebensperger \& Hurtado 2005, Hardman \& Moro 2006). Our experience of having difficulties in observing the animals in higher grass grid cells supports this explanation. In general, our findings suggest that it is not enough to know the habitat preference of a species in undisturbed situations, but to learn how and how much we should manipulate the habitat to accomplish a successful translocation action. Experiments such as ours might be helpful.

The success of a translocation should be evaluated 
on multiple temporal scales (Seddon 1999, Simms 2009). Post-release monitoring of the released ground squirrels occurred until the end of September 2007, when ground squirrels usually go into hibernation in Eastern Europe (Millesi et al. 1999). In 2008, after the first hibernation, about 30-40 individuals were only observed in an area adjacent to the release site. In 2009, this number increased to 60-80 individuals, occupying a larger area than in the preceding year. Following the generally used visual census technique (Simms 2009) and burrow counting method (Katona et al. 2002, Váczi \& Altbäcker 2005, Koshev \& Kocheva 2008, our study) to monitor ground dwelling sciurids, the population was estimated at 100-120 individuals (T. Nagy, pers. comm.). The increasing number of animals in these two years seems to fulfil the long-term requirement of a 'successful translocation' (Seddon 1999).

Finally, our experiments support the notion that long-time persistence, which primarily depends on longevity and reproductive success, is strongly connected to the first period after release of the translocated animals, and habitat manipulation at the release site may significantly contribute to successful settlement during this critical period (Letty et al. 2007, Moorhouse et al. 2009).

Acknowledgements - this study was accomplished in the framework of the Falco cherrug LIFE programme (LIFE06 $\mathrm{NAT} / \mathrm{H} / 000096)$. We are extremely grateful to Tamás Nagy, State Ranger Service, Kiskunság National Park Directorate, for his still ongoing collaboration, enthusiasm and help with this study. In addition, we express our thanks to the anonymous reviewers, the associate editors and editor-in-chief for their useful and helpful comments, to Mrs. Szilvia Vass-Meyndt for improving the quality of the photo, and in particular to Lee C. Drickamer for thoroughly editing the text. Duna-Ipoly National Park Directorate and Alsó-Tisza-vidéki Environment, Nature Protection and Water Authority gave permission to the scientific work on the protected species (permission number: 1231/1/2007). The experiments comply with the current laws of the Republic of Hungary.

\section{References}

Anstee, S. \& Armstrong, K. 2001: The effect of familiarity and mound condition in translocations of the western pebble-mound mouse, Pseudomys chapmani, in the Pilbara region of Western Australia. - Wildlife Research 28: 135-140.

Bajomi, B., Pullin, A.S., Stewart, G.B. \& Takács-Sánta, A. 2010: Bias and dispersal in the animal reintroduction literature. - Oryx 44: 358-365.
Calvete, C. \& Estrada, R. 2004: Short-term survival and dispersal of translocated European wild rabbits. Improving the release protocol. - Biological Conservation 120: 507-516.

Cheyne, S.M. 2006: Wildlife reintroduction: considerations of habitat quality at the release site. - BMC Ecology 6: 5.

Ebensperger, L.A. \& Hurtado, M.J. 2005: On the relationship between herbaceous cover and vigilance activity of degus (Octodon degus). - Ethology 111: 593-608.

Fischer, J. \& Lindenmayer, D.B. 2000: An assessment of the published results of animal relocations. - Biological Conservation 96: 1-11.

Gedeon, Cs.I., Váczi, O., Koósz, B. \& Altbäcker, V. 2011: Morning release into artificial burrows with retention caps facilitates success of European ground squirrel (Spermophilus citellus) translocations. - European Journal of Wildlife Research 57: 1101-1105.

Gerber, L.R., Seabloom, E.W., Burton, R.S. \& Reichman, O.J. 2003: Translocation of an imperilled woodrat population: integrating spatial and habitat patterns. - Animal Conservation 6: 309-316.

Google Earth ${ }^{\text {TM: }}$ 'Szeri-puszta' 46³1'19.83"N and 2004"47.48"E. - Available at: http://earth.google.com (Last accessed on 24 March 2011).

Griffith, B., Scott, M.J., Carpenter, J.W. \& Reed, C. 1989: Translocation as a Species Conservation Tool: Status and Strategy. - Science 245: 477-480.

Hardman, B. \& Moro, D. 2006: Importance of diurnal refugia to a hare-wallaby reintroduction in Western Australia. - Wildlife Research 33: 355-359.

Hoffmann, I.E., Turrini, T. \& Brenner, M. 2008: Do European ground squirrels in Austria adjust their life history to anthropogenic influence? - Lynx 39: 241-250.

Hulová, Š. \& Sedláček, F. 2008: Population genetic structure of the European ground squirrel in the Czech Republic. - Conservation Genetics 9: 615-625.

Hut, R.A. \& Scharff, A. 1998: Endoscopic observations on tunnel blocking behaviour in the European ground squirrel (Spermophilus citellus). - Zeitschrift für Säugetierkunde 63: 377-380.

IUCN 1998: Guidelines for Re-Introductions. - IUCN, Gland, Switzerland and Cambridge, UK. Available at: http://www.iucnredlist.org (Last accessed on 22 January 2011).

IUCN 2010: IUCN Red List of Threatened Species. Version 2010.4. - Available at: www.iucnredlist.org (Last accessed on 22 January 2011).

IUCN 2011: 2011 IUCN Red List of Threatened Species. Available at: http://www.iucnredlist.org (Last accessed on 14 March 2011).

Katona, K., Váczi, O. \& Altbäcker, V. 2002: Topographic distribution and daily activity of the European ground squirrel population in Bugacpuszta, Hungary. - Acta Theriologica 47: 45-54.

Kis, J., Váczi, O., Katona, K. \& Altbäcker, V. 1998: A növényzet magasságának hatása a cinegési ürgék élőhe- 
lyválasztására. (In Hungarian with an English summary: The effect of vegetation height to habitat selection of ground squirrels in Cinegés.) - Természetvédelmi Közlemények 7: 117-123.

Koshev, Y. \& Kocheva, M. 2008: Daily activity pattern in free-living European ground squirrels Spermophilus citellus (Mammalia: Rodentia) from Northwestern Bulgaria. Acta Zoologica Bulgarica Suppl. 2: 149-154.

Letty, J., Marchandeau, S. \& Aubineau, J. 2007: Problems encountered by individuals in animal translocations: Lessons from field studies. - Ecoscience 14: 420-431.

Massei, G., Quy, R.J., Gurney, J. \& Cowan, D.P. 2010: Can translocations be used to mitigate human-wildlife conflicts? - Wildlife Research 37: 428-439.

Miller, B., Ralls, K., Reading, R.P., Scott, J.M. \& Estes, J. 1999: Biological and technical considerations of carnivore translocation: a review. - Animal Conservation 2: 59-68.

Millesi, E., Huber, S., Dittami, J., Hoffmann, I. \& Daan, S. 1998: Parameters of mating effort and success in male European ground squirrel, Spermophilus citellus. - Ethology 104: 298-313.

Millesi, E., Huber, S., Everts, L.G. \& Dittami, J.P. 1999 Reproductive decisions in female European ground squirrels: Factors affecting reproductive output and maternal investment. - Ethology 105: 163-175.

Moorhouse, T.P., Gelling, M. \& Macdonald, D.W. 2009: Effects of habitat quality upon reintroduction success in water voles: Evidence from a replicated experiment. Biological Conservation 142: 53-60.

Rouco, C., Ferreras, P., Castro, F. \& Villafuerte, R. 2008: The effect of exclusion of terrestrial predators on shortterm survival of translocated European wild rabbits. Wildlife Research 35: 625-632.

Ružić, A. 1978: Citellus citellus (Linnaeus, 1766) Der oder das Europäische Ziesel. - In: Niethammer, J. \& Krapp, F.
(Eds); Handbuch der Säugetiere Europas. Band 1, Nagetiere I. Akademische Verlagsgesellschaft, Wiesbaden, Germany, pp. 123-144.

Seddon, P.J. 1999: Persistence without intervention: assessing success in wildlife reintroductions. - Trends in Ecology and Evolution 14: 503.

Seddon, P.J., Armstron, P. \& Maloney, R.F. 2007: Developing the science of reintroduction biology. - Conservation Biology 21: 303-312.

Simms, K. 2009: Reintroduction of Black-tailed prairie dogs. - BLM Tucson Field Office, Las Cienegas, NCA, Tuscon, Arizona, USA, 32 pp.

StatSoft Inc. 2009: STATISTICA (data analysis software system). Version 9.0. - StatSoft Inc., Tulsa, Oklahoma, USA.

Teixeira, C.P., Schtinil de Azevedo, C., Mendl, M., Cipreste, C.F. \& Young, R.J. 2007: Revisiting translocation and reintroduction programmes: the importance of considering stress. - Animal Behaviour 73: 1-13.

Truett, J.C., Dullum, J.A.L.D., Matchett, M.R., Owens, E. \& Seery, D. 2001: Translocating prairie dogs: a review. Wildlife Society Bulletin 29: 863-872.

Turrini, T., Brenner, M., Millesi, E. \& Hoffmann, I.E. 2008: Home ranges of European ground squirrels in two habitats exposed to different degree of human impact. Lynx 39: 333-342.

Váczi, O. \& Altbäcker, V. 2005: Monitoring of protected and threatened species. Mammals: European Ground squirrel (Spermophilus citellus). - Available at: http:// www.termeszetvedelem.hu/index.php?pg=sub_618 (Last accessed on 19 November 2010).

Váczi, O., Koósz, B. \& Altbäcker, V. 2006: Modified ambient temperature perception affects daily activity patterns in the European ground squirrel (Spermophilus citellus). - Journal of Mammalogy 87: 54-59. 